\title{
ANALISIS KEIKUTSERTAAN INDONESIA DALAM LIBERALISASI MULTILATERAL TERHADAP KINERJA SEKTOR BERAS DAN GULA DALAM MEWUJUDKAN KETAHANAN PANGAN
}

\author{
Adrian D. Lubis ${ }^{1}$ dan Reni K. Arianti ${ }^{1}$ \\ ${ }^{1}$ Pusat Kebijakan Kerjasama Perdagangan Internasional, \\ Badan Pengkajian dan Pengembangan Kebijakan Perdagangan, \\ Kementerian Perdagangan Republik Indonesia \\ Artikel diterima Mei 2012 \\ Artikel disetujui untuk dipublikasikan Juli 2012
}

\begin{abstract}
Lots of people believe that multilateral liberalization will reduce Indonesia capability to maintain national food security, especially for rice and sugar. However, this study that use multiregression analysis with dummy variabel and GTAP found that import of rice and sugar increase due to lack of capability to fulfill national consumption. Therefore, Indonesia must increase its rice and sugar productivity to fulfill national food security in liberalization regime.
\end{abstract}

Keywords: Trade Liberalization, Food Security, Multiregression, GTAP Model

\begin{abstract}
ABSTRAK
Banyak orang percaya bahwa liberalisasi multilateral akan mengurangi kemampuan Indonesia untuk menjaga ketahanan pangan nasional, khususnya beras dan gula. Akan tetapi, penelitian ini, yang menggunakan analisis multiregresi (multiregression analysis) dengan variabel dummy dan GTAP, menemukan bahwa meningkatnya impor beras dan gula disebabkan oleh kurangnya kemampuan dalam memenuhi konsumsi nasional. Karena itu, Indonesia harus meningkatkan produktivitas beras dan gula untuk memantapkan ketahanan pangan nasional dalam rezim liberalisasi.
\end{abstract}

Kata kunci: Liberalisasi Perdagangan, Ketahanan Pangan, multiregresi, Model GTAP

\section{Pendahuluan}

Meningkatnya keterkaitan industri yang berasal dari beberapa negara sebagai dampak kegiatan merger internasional dan akuisisi menyebabkan dibutuhkannya kebijakan perdagangan yang relatif sama. Susastro (2004) menemukan bahwa liberalisasi merupakan salah satu langkah efektif dalam meningkatkan daya saing nasional di pasar global. Kondisi ini tercipta karena liberalisasi mendorong kinerja perekonomian menjadi lebih efisien melalui aplikasi teknologi baru sebagai implementasi liberalisasi di sektor perdagangan dan investasi.
Liberalisasi melalui rangkaian kerjasama bilateral maupun regional merupakan kondisi yang tidak dapat dihindari lagi. Tingginya kuantitas perjanjian liberalisasi memberikan indikasi setiap negara sangat tergantung dengan negara tetangganya baik di tingkat bilateral maupun regional.

Keterkaitan negara ASEAN dengan negara di sekitarnya. Sebagai salah satu bagian dari ASEAN, Indonesia tidak dapat melepaskan diri dari keterkaitan bersama negara tetangga anggota ASEAN seperti Malaysia, Thailand, Singapura, dan negara anggota ASEAN lain. Selanjutnya, ASEAN ternyata tidak dapat memisahkan 
diri dari mitra tradisional ASEAN di wilayah timur terutama Jepang, Rep. Korea dan Rep. Rakyat China serta mitra utama di selatan yaitu Australia, India dan Selandia Baru. Keterkaitan ASEAN dengan mitra di Asia Timur semakin kokoh dengan kerjasama liberalisasi regional yang diwacanakan dalam konsep ASEAN plus 3. Sedangkan kerjasama ASEAN dengan Australia, India dan Selandia Baru semakin meningkat dengan serangkaian konsep kerjasama dalam fora East Asia Summit (EAS).

Konsep kerjasama regional tersebut diwujudkan dengan serangkaian perjanjian liberalisasi perdagangan bilateral maupun regional. Bentuk kerjasama liberalisasi perdagangan bilateral antara lain Indonesia - Jepang, sedangkan liberalisasi regional adalah ASEAN Free Trade Agreement (AFTA), ASEAN-Korea, ASEANAustralia-Selandia Baru, dan ASEANChina. Liberalisasi tersebut bahkan dianggap masih belum mencukupi, dimana ASEAN plus 3 masih berusaha meningkatkan kerjasama mereka dengan negara Uni Eropa melalui ASEAN European Meeting (ASEM) dan dengan sesama negara dilaut Pasific melalui Asia Pacific Economic Community (APEC).

Liberalisasi ini mau atau tidak harus dilakukan Indonesia jika ingin terlibat dalam lingkup perdagangan internasional. Hal ini menyebabkan integrasi dinamika perdagangan global dengan ketahanan ekonomi nasional menjadi salah satu pokok strategis pembangunan perdagangan (Kementerian Perdagangan, 2009). Salah satu langkah integrasi dengan cakupan terluas dan mungkin akan memberikan dampak terbesar bagi Indonesia adalah liberalisasi dalam fora multilateral melalui keanggotaan Indonesia sebagai anggota World Trade Organization (WTO).

Perjuangan Indonesia didalam forum Multilateral dilakukan melalui perundingan perdagangan internasional dibawah naungan World Trade Organization (WTO). Indonesia sejak tahun 2003 telah meningkatkan perannya sebagai salah satu key player dalam perundingan dengan memimpin Kelompok 33 (G33) yang memperjuangkan perlindungan terhadap petani kecil/miskin dan pembangunan pedesaaan melalui proposal "Special Products" (SP) dan "Special Safeguard Mechanism" (SSM), pengurangan dan penghapusan subsidi domestik dan subsidi ekspor di negaranegara maju, dan tetap memperjuangkan fleksibilitas lainnya bagi negara berkembang seperti penurunan tariff, deminimis subsidi dan lain sebagainya. Selain itu melalui kelompok 11 ( NAMA 11) Indonesia juga berjuang mendapatkan fleksibilitas penurunan tariff untuk barangbarang Industri, serta perubahan mengenai peraturan/rules yang selama ini dirasakan tidak adil seperti antidumping dan subsidi. Dengan meningkatnya peran Indonesia di dalam perundingan di WTO Indonesia selalu diundang dalam pertemuan kelompok-kelompok kecil yang berpengaruh menentukan arah perundingan. Dengan demikian Indonesia telah dapat memberikan kontribusinya dalam semua sektor perundingan dan tentunya dengan memperhatikan kepentingan nasional.

Perundingan Doha Development Agenda (DDA) di WTO telah berlangsung sekitar 8 tahun, sampai saat ini masih belum satupun isu perundingan dapat diselesaikan. Perundingan akan segera dimulai kembali setelah terjadi kegagalan bulan Juli 2008 dan diharapkan dapat dirampungkan dalam tahun 2010. Jika negosiasi tersebut berhasil dirampungkan, akan terjadi liberalisasi produk barang dan jasa yang akan dilaksanakan serempak di seluruh dunia.

Liberalisasi tersebut akan mengurangi proteksi domestik dan meningkatkan impor produk pertanian di dunia, khususnya Indonesia. Namun dalam menganalisis dampak liberalisasi 
multilateral perlu dianaliai beberapa hal yaitu 1. faktor apakah yang mempengaruhi impor produk pertanian, 2. Bagaiman dampak keikutsertaan Indonesia dalam liberalisasi WTO terhadap kinerja sektor pertanian dalam memenuhi ketahanan pangan, dan 3. bagaimanakah Indonesia menyikapi dampak liberalisasi tersebut untuk dapat meningkatkan kinerja sektor pertanian dalam memenuhi ketahanan pangan?

Kajian ini berusaha untuk menjawab permasalahan tersebut dengan menggunakan: Pertama, data perdagangan yang diterbitkan oleh Statistik Indonesia maupun devisi statistik dari Food and Agriculture Organization (FAO) untuk menganalisa lonjakan impor produk pertanian di Indonesia. Kedua, data perubahan produksi dan konsumsi produk pangan yaitu beras dan gula dari devisi statistik FAO. Ketiga, data primer yang bertujuan mengkontrol hasil prediksi dengan kondisi riil di lapangan.

Adapun metodologi yang digunakan adalah persamaan regresi berganda dengan variabel dummy yang diilhami oleh model gravitasi yang dibangun McCallum (1995). Berdasarkan model tersebut dibangun persamaan 1 untuk memprediksi dampak perubahan kinerja perekonomian khususnya GDP, dan liberalisasi terhadap impor produk beras dan gula nasional sebagai berikut :

$\ln M_{i j}=a_{1}+a_{2} \ln y_{i}+a_{3} \ln p_{i}+a_{4} \ln c_{i}+a_{5} \ln d_{i j}+\cdots+\varepsilon_{i j} \ldots$ (1)

dimana :

$M_{i j}=$ impor Indonesia untuk komoditas beras atau gula dari dunia

$y_{i}=$ nilai GDP Indonesia, $p$ adalah produksi komoditas beras dan gula nasional,

$c_{i}=$ konsumsi komoditas beras dan gula nasional

$d=$ dummy liberalisasi yaitu AFTA, KAFTA, IJEPA
Selanjutnya akan dilakukan simulasi untuk memprediksikan dampak liberalisasi dengan menggunakan model keseimbangan umum Global Trade Analysis Project (GTAP) versi 6. Adapun simulasi yang dilakukan terdiri simulasi A, yaitu dampak liberalisasi yang sudah terjadi antara Indonesia dengan sesama negara ASEAN yang dikenal dengan ASEAN Free Trade Agreement (AFTA), Korea ASEAN Free Trade Agreement (KAFTA) dan Indonesia Jepang Economic Partnership Agreement (IJEPA). Selanjutnya dilakukan simulasi B yaitu simulasi A ditambah dengan prediksi dampak liberalisasi sesuai perjanjian WTO.

\section{Studi Terkait Negosiasi WTO}

Menurut Apriyantono (2006), jika ditelusuri ke belakang, pada saat kita berbicara soal Liberalisasi Perdagangan, sebenarnya upaya global itu telah dimulai sejak tahun 1947 dengan dirancangnya General Agreement on Tariffs and Trade (GATT). Negosiasi tentang perdagangan ini memakan waktu cukup lama, sampai delapan putaran, yang berakhir tahun 1994. Pada putaran terakhir, Putaran Uruguay, yang berlangsung dalam periode 1986-1994, dan ditutup di Marakesh, Moroko pada awal 1994, dibentuk badan perdagangan dunia yang kemudian dikenal nama World Trade Organization (WTO).

Dalam delapan putaran itu, dan juga Putaran Doha sekarang ini, pembahasan tentang liberalisasi perdagangan sangat terfokus pada pengurangan tingkat tarif. Semuanya terkait dengan akses pasar (market access). Artinya, perdagangan internasional telah terperangkap pada sisi permintaan (demand side) dan mengabaikan sisi penawaran (supply side). Padahal, memecahkan hambatan dari sisi penawaran sangat erat kaitannya dengan kemampuan negara berkembang untuk 
dapat meraih keuntungan dari terbukanya akses pasar (Apriyantono, 2006).

Pentingnya sisi penawaran dalam perdagangan internasional telah diungkapkan oleh Rubens Ricupero, mantan Sekjen UNCTAD, pada suatu pertemuan Trade and Development Board UNTAD, di Jenewa 15 Oktober 2003 lalu. Ia mengatakan antara lain: "Akar masalah dari keengganan banyak negara berkembang untuk terlibat dalam liberalisasi perdagangan, karena mereka tidak cukup kompetitif, disamping mereka sendiri mengandalkan pada dua-tiga jenis komoditas saja untuk ekspor" (Apriyantono, 2006).

Apriyantono (2006) menyatakan banyak kendala yang dihadapi negaranegara berkembang, termasuk Indonesia, dalam memperkuat dan memanfaatkan sisi penawaran, seperti masalah kualitas SDM, energi, infrastruktur yang meliputi sarana prasarana transportasi (termasuk pelabuhan), teknologi komunikasi dan informasi. Aspek lainnya yang tidak kalah penting adalah kestabilan politik dan ekonomi. Apabila ke dua sisi itu tercapai, maka hal tersebut akan memperkuat kapasitas produktif, mengurangi ongkos, serta meningkatkan daya saing. Selanjutnya, sisi penawaran penting lainnya adalah membuka akses sektor Usaha Kecil Menengah (UKM) terhadap pendanaan (finance), meningkatkan kuantitas dan kualitas pelayanan buat mereka, perbaikan manajemen dan keahlian. Itu kemudian dapat dibuat agar mereka terkait dengan global supply chain (rantai pasokan global), bukan seperti sekarang ini.

\section{Namun, Bursfier}

menyatakan bahwa hambatan perdagangan untuk produk pertanian dan subsidi meningkatkan biaya bagi negara tersebut dan mitra dagangnya. Hambatan perdagangan mengurangi permintaan produk di negara mitra, namun disisi lain subsidi menyebabkan kelebihan produksi domestik. Kedua kebijakan tersebut jika terjadi bersamaan akan menyebabkan turunnya harga produk pertanian. Bursfier menyatakan bahwa eliminasi distorsi perdagangan akan meningkatkan kesejahteraan penduduk dunia sebesar US $\$ 56$ miliar. Adapun instrumen yang umum digunakan dalam hambatan perdagangan adalah tarif. Oleh karena itu, di tahun 2010, negara anggota WTO sepakat melakukan reformasi perdagangan melalui serangkaian kebijakan penurunan tarif dan subsidi.

Gambar 1 menunjukkan perubahan hambatan tarif semenjak negosiasi Uruguay Round sampai negosiasi Doha Development Agenda saat ini. Hasil negosiasi Uruguay Round adalah kesepakatan penurunan tarif menjadi maksimal 100 persen. Selanjutnya, tarif tersebut dalam negosiasi Doha Development Agenda diusahakan untuk turun lagi menjadi maksimal 50 persen. Tarif maksimal 50 persen adalah tarif tertinggi yang dapat diaplikasikan atau dikenal dengan bound rate. Jika terdapat petani dari produk pertanian tertentu mengalami kerugian akibat liberalisasi tersebut, masih dapat diselamatkan melalui mekanisme special safeguard mechanism (SSM).

Saat ini terdapat 2 hal teknis yang sangat penting dalam negoisasi WTO selanjutnya. Pertama, yakni besaran remedy yang dapat diterapkan berikut dengan besaran rentang lonjakan. Kedua, cara dalam menentukan besaran trigger. Pendekatan yang selama ini diusulkan dan cukup banyak diterima adalah dengan menggunakan Moving Average (MA), khususnya MA 3. Beberapa pendekatan lain yang sempat diwacanakan adalah penggunaan MA 5, fixed reference prices dan olympic average price (dengan menghilangkan nilai yang terbesar dan terkecil, setelah itu baru dihitung rataratanya). Kedua poin ini yang terus menerus dinegoisasikan selain dari tuntutan negara berkembang agar negara 
maju mau menurunkan dan bahkan menghilangkan subsidi ekspor yang mereka berikan.

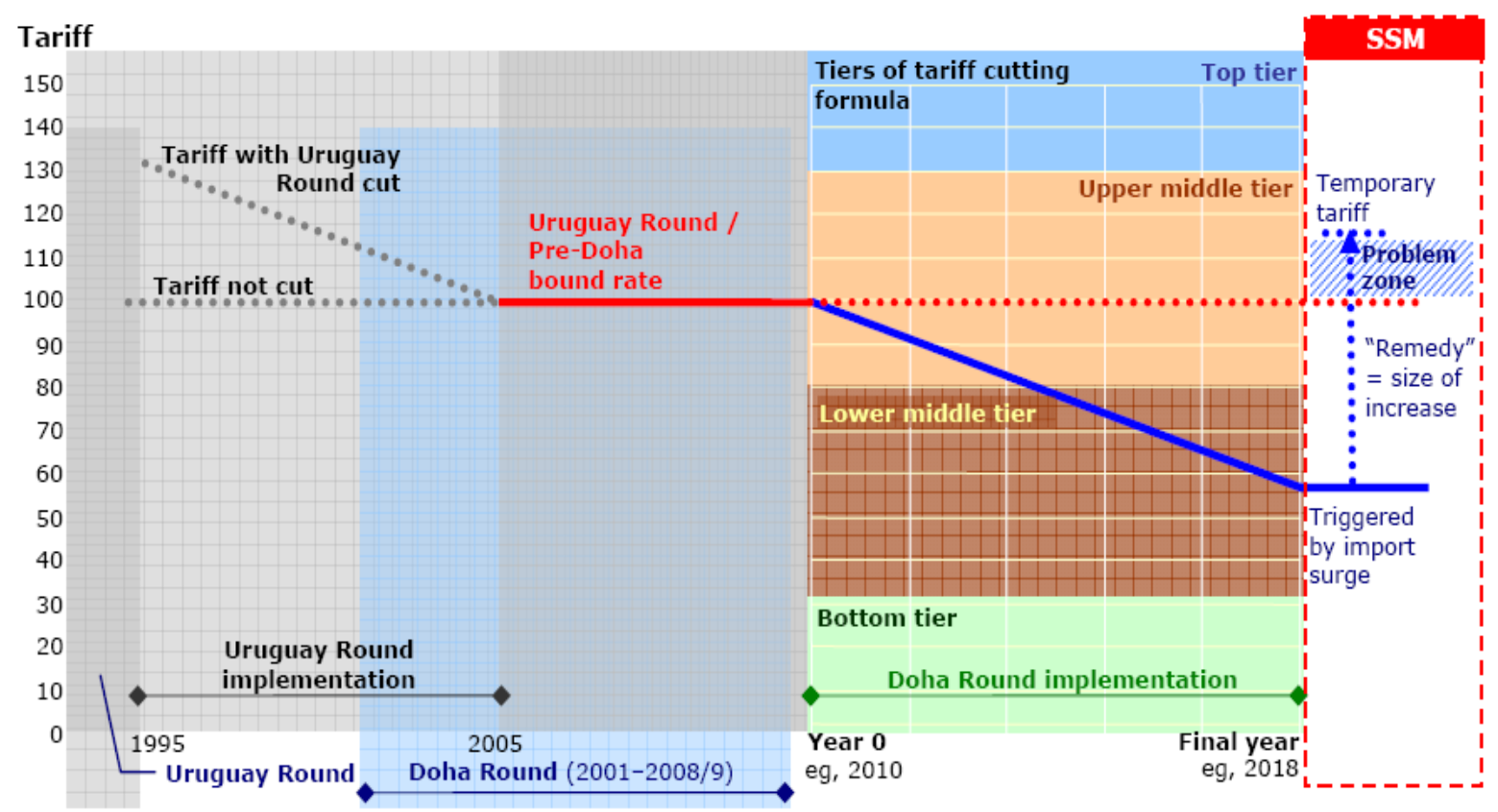

Sumber: WTO (2008)

\section{Gambar 1. Skema Liberalisasi Multilateral}

Jika perhitungan trigger didasarkan pada harga, maka kejatuhan harga didefinisikan sebagai perubahan harga relatif terhadap rata-rata harga impor tiga tahun sebelumnya. SSM akan berlaku jika terjadi kejatuhan harga c.i.f sebesar 85 persen dari rata-rata harga impor tiga tahun sebelumnya. Besaran remedy yang diterapkan adalah sebesar 85 persen dari perbedaan harga impor dan harga trigger.

\section{Perlakuan Spesial dan Berbeda bagi Negara Berkembang dalam Negosiasi WTO}

Negara berkembang menerima perlakuan yang berbeda mengenai perhitungan safeguard yang disebut special and differential treatment, dalam hal pengecualian de minimis volume impor. Sebagai pengguna safeguard, negara berkembang menerima perlakuan berbeda untuk menghargai perhitungan mereka masing-masing, misalnya dengan mengecualikan durasi perpanjangan.

Pada konsep pengecualian impor de minimis, langkah safeguard tidak dapat diterapkan untuk menekan volume ekspor dari negara berkembang. Yaitu, ketika impor dari suatu negara berkembang kurang dari 3 persen dari total impor pada produk yang diteliti. Dalam klausul ini, negara berkembang yang berada dibawah ambang tersebut secara individu dan secara kolektif lebih dari 9 persen dari impor tersebut, impor tersebut dapat dikeluarkan dari perhitungan.

Dalam pemberlakuan konsep safeguard, negara-negara berkembang dapat memperpanjang kebijakan safeguard selama dua tahun ekstra dari durasi normal yang di ijinkan. Aturan-aturan untuk melaksanakan safeguard nya pun diberlakukan secara fleksibel. Misalnya periode minimum tidak diterapkan, dalam banyak kasus dalam satu setengah durasi 
dari perhitungan normal, jadi paling lama pemberlakukannya setidaknya dua tahun.

Namun perlakuan khusus ini menjadi salah satu penyebab kebuntuan pembicaraan di 2008 dipicu oleh ketidaksepakatan terkait dengan parameter trade remedies dalam mekanisme special safeguard pertanian untuk negara berkembang. Tidak ada kesepakatan dasar mengenai kondisi seperti apa yang menjadi prasyarat utama penerapan SSM. Secara spesifik, isu-isu penting yang menjadi perhatian dan menyebabkan kebuntuan pembicaraan bukan hanya seberapa besar pengaruh impor terhadap kenaikan atau penurunan harga dalam negeri sebelum trade remedies diterapkan, tetapi jika dilakukan, dengan parameter dari seberapa besar kemampuan negara berkembang menaikan tarifnya dalam kerangka tarif yang berlaku (Pra-Doha), dan seberapa banyak produk yang dapat dilibatkan.

\section{Perubahan Luas Areal Padi dan Gula}

Salah satu indikasi penting perubahan produksi beras dan gula nasional adalah luas areal beras dan tebu. Perubahan luas areal kedua produk tersebut dapat dilihat selengkapnya dalam Gambar2. Luas areal padi selama tahun 1990 sampai dengan tahun 2009 menunjukkan pertumbuhan yang signifikan. Luas areal padi di tahun 1990 mencapai 10,5 juta HA dan meningkat di tahun 2009 mencapai 12,8 juta hektar (Ha). Peningkatan ini relatif signifikan selama periode 1990-2009, meskipun terjadi fluktuasi dalam beberapa tahun.

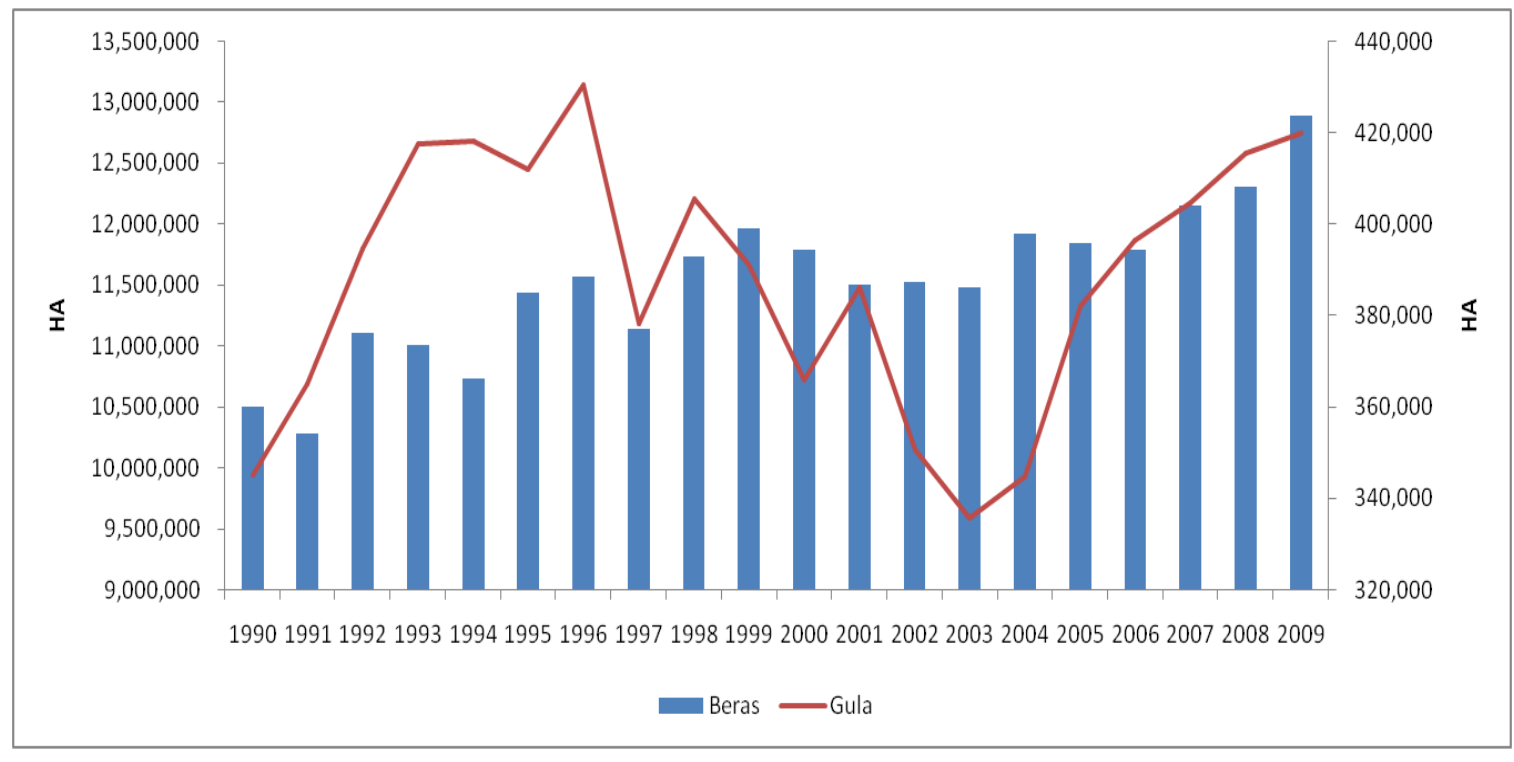

Sumber : www.fao.org

Gambar 2. Luas Areal Padi dan Gula

Luas areal tebu relatif lebih berfluktuasi dibandingkan luas areal beras. Luas areal tebu mengalami peningkatan dari $345.000 \mathrm{Ha}$ di tahun 1990 menjadi 420.000 Ha di tahun 2009. Namun, di tahun 1996 sampai tahun 2003 luas areal tebu mengalami penurunan drastis dari $430.361 \mathrm{Ha}$ menjadi $335.725 \mathrm{Ha}$.

\section{Produksi Beras dan Gula}

Produksi beras selama tahun 1990 sampai 2009 menunjukkan pertumbuhan signifikan. Produksi beras di tahun 1990 mencapai 45,17 juta ton dan meningkat menjadi 64,39 juta ton di tahun 2009. 
Pertumbuhan ini menunjukkan produksi tahun selama periode tersebut. beras bertambah sebesar 1,17 persen per

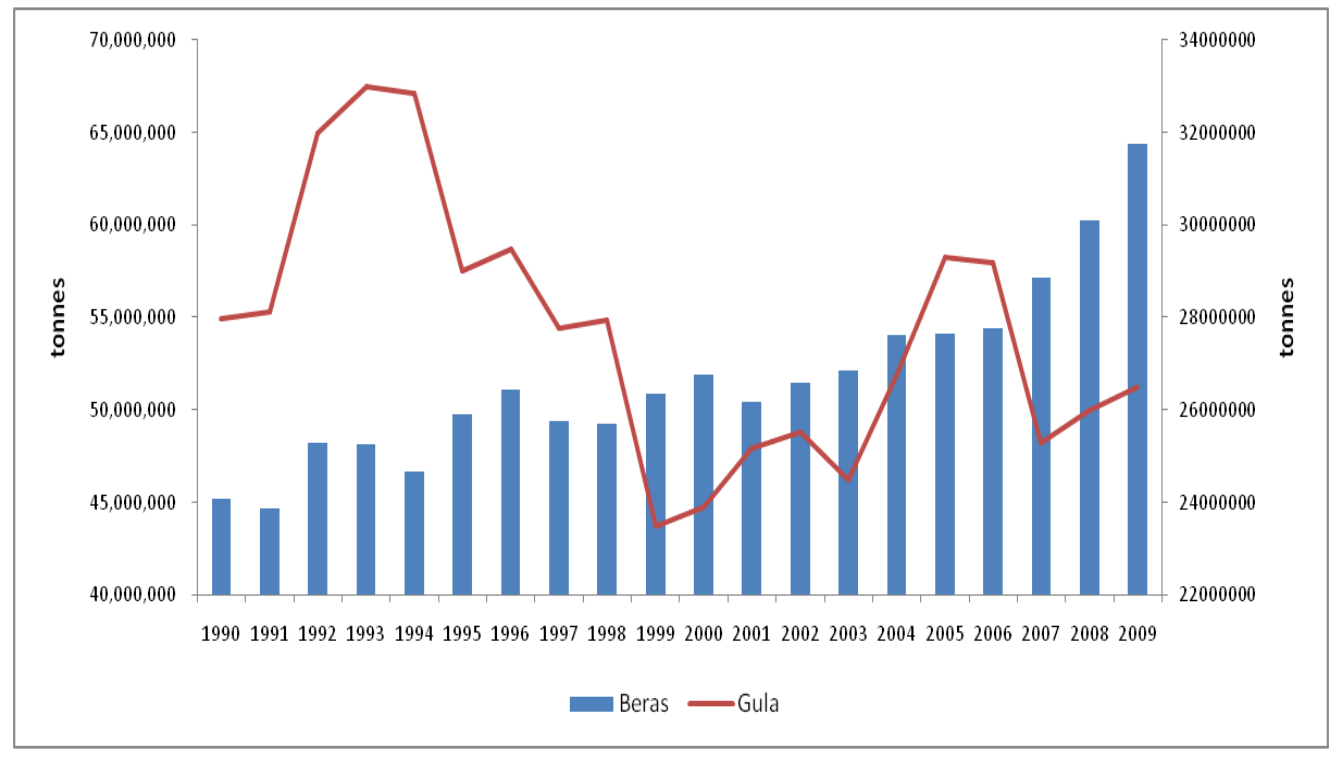

Sumber : www.fao.org

Gambar 3. Produksi Beras dan Gula

Sedangkan produksi gula selama periode tersebut ternyata sangat fluktuatif. Produksi gula di tahun 1990 mencapai 27,97 juta ton, dan meningkat menjadi 33 juta di tahun 1993. Namun, setelah tahun tersebut, produksi gula turun mencapai titik terendah, mencapai 23,5 juta di tahun
1999. Selanjutnya produksi gula mengalami peningkatan mencapai titik tertinggi di taun 2005, namun kembali menurun dan akhirnya di tahun 2009 produksi gula nasional mencapai 26,5 juta ton.

Tabel 1 . Perbandingan Produksi 20 Produk Pertanian dan Peternakan di Tahun 1990-2009

\begin{tabular}{|c|c|c|c|c|c|c|c|c|c|}
\hline Rank & Komoditas & $\begin{array}{l}\text { Produksi } \\
\text { (Int \$1000) }\end{array}$ & $\begin{array}{l}\text { Produksi } \\
\text { (MT) }\end{array}$ & $\begin{array}{l}\text { Harga Per } \\
\text { Unit } \\
\text { (US \$ per } \\
\text { MT) }\end{array}$ & Rank & Komoditas & $\begin{array}{l}\text { Produksi } \\
\text { (Int \$1000) }\end{array}$ & $\begin{array}{l}\text { Produksi } \\
\text { (MT) }\end{array}$ & $\begin{array}{l}\text { Harga } \\
\text { Per } \\
\text { Unit } \\
\text { (US \$ } \\
\text { per } \\
\text { MT) }\end{array}$ \\
\hline \multicolumn{5}{|c|}{ Tahun 1990} & \multicolumn{5}{|c|}{ Tahun 2009} \\
\hline 1 & Rice, paddy & $9,339,796$ & $45,178,752$ & 206.73 & 1 & Rice, paddy & $12,440,012$ & $60,251,072$ & 206.47 \\
\hline 2 & Cassava & $1,117,840$ & $15,829,635$ & 70.62 & 2 & Palm oil & $5,116,644$ & $16,900,000$ & 302.76 \\
\hline 3 & Coconuts & $1,096,132$ & $12,120,000$ & 90.44 & 3 & $\begin{array}{l}\text { Indigenous } \\
\text { Chicken } \\
\text { Meat }\end{array}$ & $1,775,825$ & $1,522,458$ & $\begin{array}{r}1,166.4 \\
2\end{array}$ \\
\hline 4 & Palm oil & 730,442 & $2,412,612$ & 302.76 & 4 & Coconuts & $1,763,580$ & $19,500,000$ & 90.44 \\
\hline 5 & Maize & & & 107.87 & 5 & Natural & & & \\
\hline
\end{tabular}




\begin{tabular}{|c|c|c|c|c|c|c|c|c|c|}
\hline Rank & Komoditas & $\begin{array}{l}\text { Produksi } \\
\text { (Int \$1000) }\end{array}$ & $\begin{array}{l}\text { Produksi } \\
\text { (MT) }\end{array}$ & $\begin{array}{l}\text { Harga Per } \\
\text { Unit } \\
\text { (US \$ per } \\
\text { MT) }\end{array}$ & Rank & Komoditas & $\begin{array}{l}\text { Produksi } \\
\text { (Int \$1000) }\end{array}$ & $\begin{array}{l}\text { Produksi } \\
\text { (MT) }\end{array}$ & $\begin{array}{l}\text { Harga } \\
\text { Per } \\
\text { Unit } \\
\text { (US \$ } \\
\text { per } \\
\text { MT) }\end{array}$ \\
\hline \multicolumn{5}{|c|}{ Tahun 1990} & \multicolumn{5}{|c|}{ Tahun 2009} \\
\hline & & 726,369 & $6,734,028$ & & & rubber & $1,567,233$ & $2,921,872$ & 536.38 \\
\hline 6 & $\begin{array}{l}\text { Natural } \\
\text { rubber }\end{array}$ & 684,042 & $1,275,295$ & 536.38 & 6 & Cassava & $1,524,288$ & $21,593,052$ & 70.59 \\
\hline 7 & $\begin{array}{l}\text { Indigenous } \\
\text { Chicken } \\
\text { Meat }\end{array}$ & 581,481 & 498,518 & 1166.42 & 7 & Maize & $1,286,208$ & $16,323,922$ & 78.79 \\
\hline 8 & Sugar cane & 581,136 & $27,979,632$ & 20.77 & 8 & $\begin{array}{l}\text { Hen eggs, } \\
\text { in shell }\end{array}$ & 874,259 & $1,122,617$ & 778.77 \\
\hline 9 & $\begin{array}{l}\text { Indigenous } \\
\text { Pigmeat }\end{array}$ & 560,236 & 553,237 & 1012.65 & 9 & Bananas & 818,200 & $5,741,352$ & 142.51 \\
\hline 10 & $\begin{array}{l}\text { Groundnuts, } \\
\text { with shell }\end{array}$ & 532,530 & $1,142,000$ & 466.31 & 10 & $\begin{array}{l}\text { Indigenous } \\
\text { Pigmeat }\end{array}$ & 661,741 & 653,474 & $\begin{array}{r}1,012.6 \\
5\end{array}$ \\
\hline 11 & Bananas & 343,591 & $2,410,999$ & 142.51 & 11 & $\begin{array}{l}\text { Cocoa } \\
\text { beans }\end{array}$ & 610,568 & 792,761 & 770.18 \\
\hline 12 & Soybeans & 312,112 & $1,487,433$ & 209.83 & 12 & $\begin{array}{l}\text { Palm } \\
\text { kernels }\end{array}$ & 593,287 & $4,540,000$ & 130.68 \\
\hline 13 & Beans, dry & 295,125 & 699,992 & 421.61 & 13 & $\begin{array}{l}\text { Indigenous } \\
\text { Cattle Meat }\end{array}$ & 584,391 & 282,549 & $\begin{array}{r}2,068.2 \\
8\end{array}$ \\
\hline 14 & $\begin{array}{l}\text { Fruit, } \\
\text { tropical } \\
\text { fresh nes }\end{array}$ & 194,582 & $1,700,000$ & 114.46 & 14 & $\begin{array}{l}\text { Coffee, } \\
\text { green }\end{array}$ & 558,342 & 682,938 & 817.56 \\
\hline 15 & $\begin{array}{l}\text { Sweet } \\
\text { potatoes }\end{array}$ & 176,363 & $1,971,466$ & 89.46 & 15 & Sugar cane & 540,020 & $26,000,000$ & 20.77 \\
\hline 16 & $\begin{array}{l}\text { Cabbages } \\
\text { and other } \\
\text { brassicas }\end{array}$ & 157,440 & $1,071,756$ & 146.90 & 16 & $\begin{array}{l}\text { Mangoes, } \\
\text { mangosteen } \\
s, \text { guavas }\end{array}$ & 490,175 & $2,013,123$ & 243.49 \\
\hline 17 & $\begin{array}{l}\text { Mangoes, } \\
\text { mangosteens } \\
\text {, guavas }\end{array}$ & 123,909 & 508,889 & 243.49 & 17 & Oranges & 408,170 & $2,322,581$ & 175.74 \\
\hline 18 & $\begin{array}{l}\text { Vegetables } \\
\text { fresh nes }\end{array}$ & 105,939 & 564,560 & 187.65 & 18 & $\begin{array}{l}\text { Chillies and } \\
\text { peppers, } \\
\text { green }\end{array}$ & 376,877 & $1,092,115$ & 345.09 \\
\hline 19 & Potatoes & 86,700 & 628,727 & 137.90 & 19 & $\begin{array}{l}\text { Pepper } \\
\text { (Piper spp.) }\end{array}$ & 367,966 & 79,726 & $\begin{array}{r}4,615.3 \\
8\end{array}$ \\
\hline 20 & Palm kernels & 86,248 & 660,000 & 130.68 & 20 & $\begin{array}{l}\text { Beans, } \\
\text { green }\end{array}$ & 367,524 & 837,892 & 438.63 \\
\hline
\end{tabular}

Sumber : www.fao.org

Jika dibandingkan dengan produksi produk pertanian dan peternakan lainnya, Indonesia berhasil mempertahankan produksi beras jauh diatas produk lain selama 1990-2009. Namun untuk gula tebu, mengalami penurunan dari posisi delapan terbesar di tahun 1990 menjadi posisi kelimabelas di tahun 2009. Adapun produk yang mengalami peningkatan drastis adalah kelapa sawit dan karet. Hal ini menunjukkan salah satu permasalahan dalam mempertahankan produksi pangan adalah kompetisi lahan dengan produk komersil.

\section{Konsumsi Beras dan Gula Tebu}


Konsumsi beras dan gula menunjukkan pola yang sama dengan produksi beras dan gula dalam Gambar 5 di atas. Konsumsi beras di tahun 1999 mencapai 45,78 juta ton dan meningkat sehingga mencapai 69,03 juta ton di tahun
2009. Kondisi ini memperlihatkan konsumsi beras selama 1999-2009 masih lebih besar dibandingkan kemampuan produksi nasional. Jika kondisi ini terus berlanjut, impor beras masih dibutuhkan untuk menjaga stabilitas harga beras.

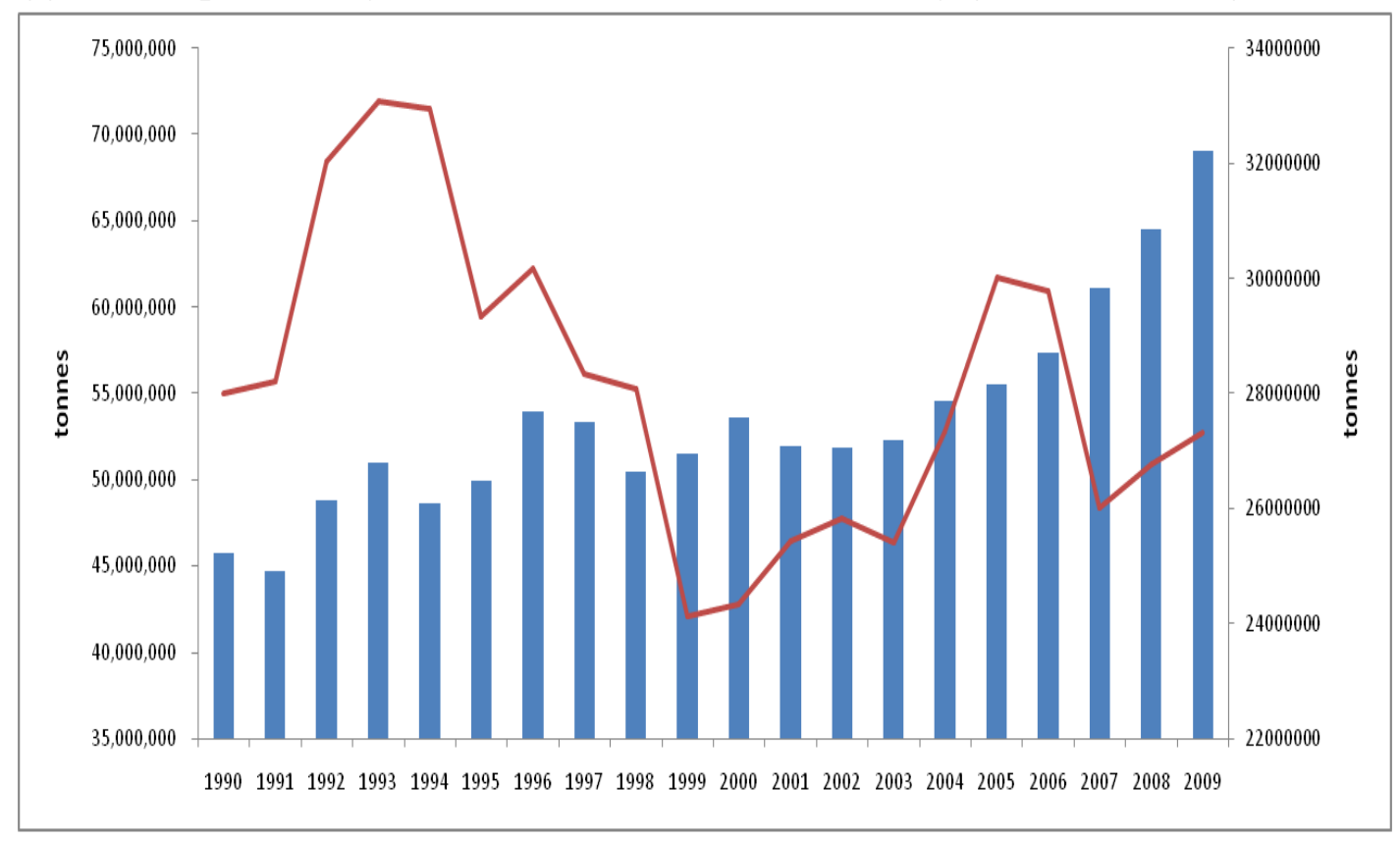

Sumber : www.fao.org

Gambar 4. Konsumsi Beras dan Gula Nasional

Adapun konsumsi gula di tahun 1999 mencapai 28 juta ton, namun di tahun 2009 turun 27,32 juta ton di tahun 2009. Angka konsumsi beras dan gula diperoleh dari konversi produksi, impor dan ekpor. Hal ini disebabkan tidak tersedianya data konsumsi gula nasional. Jika data volume riil konsumsi gula tersedia, kemungkinan nilai jauh lebih besar.

\section{Korelasi Impor dan Produksi Beras}

Selama tahun 1990 sampai dengan 2005 terdapat pola yang menunjukkan impor beras mengalami peningkatan di saat produksi beras menurun. Pola tersebut terlihat antara lain ditahun 1993, 1994 dan 1997. Namun pola tersebut mengalami perubahan semenjak tahun 2006. Nilai impor dan produksi meningkat bersamaan, mulai tahun 2006 sampai saat ini. Kondisi ini disebabkan pada periode tersebut pemerintah berhasil meningkatkan produksi melalui kebijakan ekstensifikasi dan intensifikasi pertanian. Namun, disaat bersamaan Indonesia beberapa kali mengalami bencana, sehingga perlu mengimpor beras untuk menjaga stok nasional.

Kondisi di atas menyebabkan tingginya korelasi antara produksi dengan nilai impor beras. Hasil perhitungan korelasi Pearson menunjukkan bahwa korelasi antara produksi beras dengan impor selama tahun 1990-2009 mencapai 0,68. Hal ini menunjukkan bahwa peningkatan produksi sebesar 10 persen ternyata diikuti dengan peningkatan impor sebesar 6,8 persen.

Hasil perhitungan dengan metode Pearson juga menunjukkan bahwa 
peningkatan impor juga berhubungan erat dengan nilai konsumsi. Nilai korelasi keduanya mencapai 0,75 persen, yang berarti peningkatan konsumsi sebesar 10 persen diikuti dengan peningkatan impor sebesar 7,5 persen.

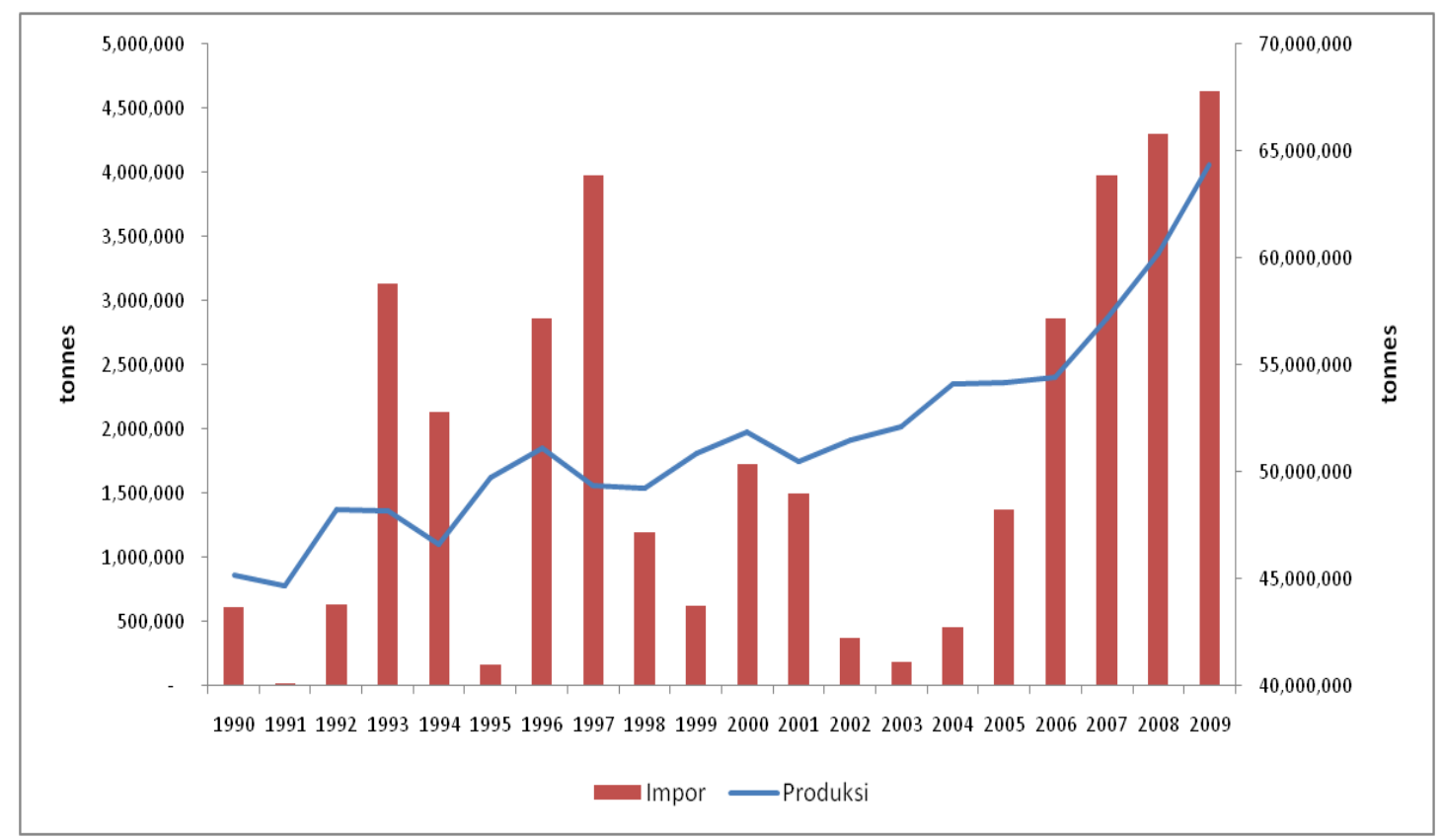

Sumber : www.fao.org

Gambar 5. Perubahan Produksi dan Impor Beras

Selain itu, berdasarkan hasil analisis regresi, ditemukan bahwa impor beras berhubungan erat dengan peningkatan volume konsumsi dan pelaksanaan liberalisasi ASEN Korea (DKAFTA). Namun volume impor beras berhubungan terbalik dengan peningkatan volume produksi, pelaksanaan liberalisasi ASEAN (DAFTA) dan Indonesia Jepang (DIJEPA). Berdasarkan hasil perhitungan, diperoleh persamaan yang mempengaruhi impor beras Indonesia sebagai berikut :

\section{Impor Beras $=-88.2+49.1$ Volume Konsumsi - 43.4 Volume Produksi - 0.33 DAFTA - 1.15 DKAFTA - 0.30 DIJEPA

Berdasarkan persamaan di atas, terlihat bahwa Indonesia mengimpor beras disebabkan kebutuhan nasional dibandingkan pelaksanaan liberalisasi.
Kondisi ini menunjukkan jika Indonesia memilih untuk melakukan proteksi untuk produk ini, diharapkan proteksi tersebut juga mempertimbangkan kebutuhan konsumsi nasional agar tidak merugikan kesejahteraan rakyat.

\section{Korelasi Impor dan Konsumsi Gula}

Perubahan produksi dan impor gula menunjukkan pola yang berlawanan selama tahun 1990-1999. Namun, pola ini mengalami perubahan semenjak tahun 2000 sapai saat ini. Setelah tahun 2000, terlihat bahwa pola impor gula mengalami perubahan tajam disaat perubahan produksi tidak signifikan. Kondisi tersebug terlihat sangat jelas selama tahun 2003 sampai tahun 2006. Semenjak tahun 2007, pola impor dan produksi menunjukkan 


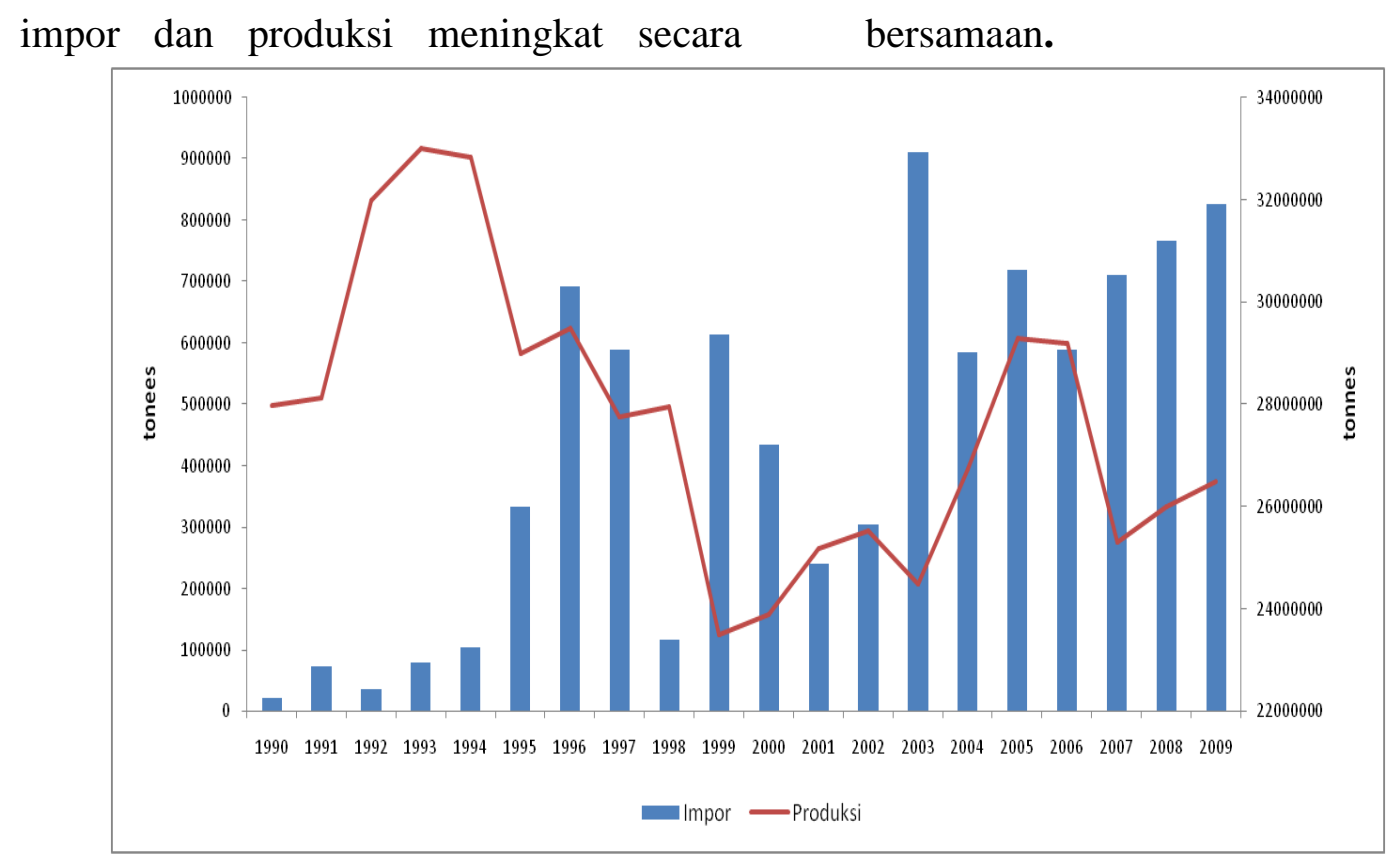

Sumber : www.fao.org

Gambar 6. Perubahan Produksi dan Impor Gula

Hasil uji korelasi Pearson menunjukkan bahwa hubungan antara produksi gula dengan impor gula adalah 0,57 . Kondisi ini menunjukkan bahwa peningkatan produksi gula sebesar 10 persen diikuti dengan penurunan impor sebesar 5,7 persen. Namun, hasil uji regresi dengan variabel berganda dan variabel dummy justru menunjukkan hal berbeda. Hasil uji regresi menunjukkan impor gula berhubungan negatif dengan volume konsumsi dan pelaksanaan liberalisasi Indonesia Jepang (DIJEPA). Namun impor tersebut berhubungan positif dengan peningkatan volume produksi, pelaksanaan liberalisasi sesama negara ASEAN (DAFTA) dan liberalisasi dengan Korea (DKAFTA). Adapun persamaan impor gula dapat dirumuskan sebagai berikut :

$$
\begin{aligned}
\text { Impor Gula } & =4.8-81.6 \text { Volume } \\
& \text { Konsumsi }+82.0 \\
& \text { Volume Produksi + } \\
& 0.073 \quad \text { DAFTA + } \\
& 0.625 \quad \text { DKAFTA - } \\
& 0.747 \text { DIJEPA.... (3) }
\end{aligned}
$$

Hasil regresi di atas menunjukkan pola yang tidak konsisten jika dibandingkan dengan pola impor beras. Adanya hubungan negatif antara konsumsi dengan impor memperlihatkan prediksi penurunan konsumsi menyebabkan importir gula membatasi impor gula. Namun, disaat bersamaan ternyata peningkatan volume produksi juga diikuti dengan peningkatan impor gula. Kondisi ini mungkin disebabkan karena tidak ada badan seperi BULOG yang saat ini menjadi penjaga stabilitas ketersediaan gula nasional, sehingga memungkinkan terjadi aktifitas pengambilan keuntungan dalam perdagangan gula nasional.

\section{Simulasi Liberalisasi WTO dan Dampaknya terhadap Produksi, Konsumsi dan Impor Produk Beras dan Gula Nasional}

Telah banyak penelitian yang dilakukan untuk memprediksi dampak liberalisasi terhadap kinerja nasional dalam menjamin ketahanan pangan. Namun, saat ini Indonesia telah melakukan liberalisasi 
perdagangan dengan mitra dagang utama

seperti terlihat dalam Tabel 2.

Tabel 2. Perubahan Tarif Indonesia dan Beberapa Negara Mitra

\begin{tabular}{|c|c|c|c|c|c|c|c|}
\hline & 2004 & 2005 & 2006 & 2007 & 2008 & 2009 & 2010 \\
\hline MFN & 9,9 & 9,9 & 9,5 & 7,8 & 7,6 & 7,5 & 7,49 \\
\hline CEPT & 3,4 & 2,8 & 2,8 & 2,0 & 1,9 & 1,9 & 0 \\
\hline ACFTA & 9,9 & 9,6 & 9,5 & 6,4 & 6,4 & 3,8 & 2,9 \\
\hline AKFTA & 9,9 & 9,9 & 9,5 & 6,6 & 6,0 & 2,6 & 2,6 \\
\hline IJEPA & 9,9 & 9,9 & 9,5 & 7,8 & 5,2 & 4,5 & 2,97 \\
\hline
\end{tabular}

Tabel di atas memperlihatkan bahwa tarif yang diberlakukan Indonesia untuk mitra dari negara ASEAN telah nol semenjak tahun 2010. Adapun tarif yang diberlakukan Indonesia untuk negara China telah mengalami penurunan signifikan semenjak tahun 2009, dan akan menjadi nol di tahun 2012 kecuali untuk beras dan gula tidak mengalami perubahan. Selanjutnya, Indonesia juga telah menurunkan tarif untuk Korea dan Jepang semenjak tahun 2007 dan dijadwalkan akan menjadi nol di tahun 2013.

Berdasarkan data di atas, terlihat bahwa tarif internasional (most favorite nations-MFN) sebesar 7,49-7,5 saat ini hanya berlaku negara yang belum memiliki perjanjian perdagangan bebas dengan Indonesia seperti Amerika Serikat, Uni Eropa, Amerika Selatan, Negara Teluk dan sekitarnya. Adapun bagi mitra lain seperti halnya India dan Australia, akan segera meratifikasi perjanjian perdagangan bebas dengan Indonesia. Menyadari kondisi di atas, maka jelas bahwa liberalisasi WTO yang diaplikasikan dengan melakukan penurunan tarif MFN diprediksikan tidak memberikan dampak sebesar liberalisasi lainnya. Adapun simulasi yang dilakukan dalam kajian ini terdiri dari dua bagian yang dapat dilihat selengkapnya dalam Tabel 3.

Tabel 3. Simulasi Liberalisasi

\begin{tabular}{|c|c|c|}
\hline Nama Simulasi & Tujuan & Deskripsi \\
\hline $\begin{array}{l}\text { A. Liberalisasi Saat Ini } \\
\text { (Simulasi A) }\end{array}$ & $\begin{array}{l}\text { Menganalisis dampak liberalisasi } \\
\text { AFTA, KAFTA, IJEPA terhadap } \\
\text { kinerja sektor pertanian dan industri } \\
\text { nasional }\end{array}$ & $\begin{array}{lr}\text { Negara yang terlibat perjanjian } \\
\text { AFTA, KAFTA, IJEPA } \\
\text { melakukan liberalisasi } & \text { kecuali } \\
\text { untuk produk } & \text { sensitif } \\
\text { Indonesia } & \end{array}$ \\
\hline $\begin{array}{l}\text { B. Liberalisasi WTO } \\
\text { (Simulasi B) }\end{array}$ & $\begin{array}{l}\text { Menganalisis dampak liberalisasi } \\
\text { AFTA, KAFTA, IJEPA dan WTO } \\
\text { terhadap kinerja sektor pertanian } \\
\text { dan industri nasional }\end{array}$ & $\begin{array}{l}\text { Negara yang terlibat perjanjian } \\
\text { AFTA, KAFTA, IJEPA, WTO } \\
\text { melakukan liberalisasi kecuali } \\
\text { untuk produk sensitif } \\
\text { Indonesia }\end{array}$ \\
\hline
\end{tabular}


Produk sensitif yang ada dimaksud dalam simulasi ini adalah produk sensitif Indonesia yang terdiri dari beras/padi, gula, dan minuman keras. Adapun produk lainnya dalam negosiasi tersebut umumnya dimasukkan kedalam kelompok normal good yang akan mengalami penghapusan tarif dalam perjanjian liberalisasi AFTA, KAFTA, dan IJEPA. Khusus untuk liberalisasi WTO, dilakukan dengan melakukan liberalisasi saat ini ditambah dengan penurunan tarif WTO sesuai proposal yang ada.

\subsection{Dampak Liberalisasi Terhadap Surplus Perdagangan dan Kesejahteraan}

Hasil analisis menunjukkan bahwa liberalisasi yang saat ini telah berlangsung menyebabkan penurunan surplus perdagangan untuk produk sensitif Indonesia dan produk jasa, namun memberikan peningkatan untuk pertanian lain dan manufaktur. Hasil analisis selengkapnya tercantum dalam Tabel 4.

Berdasarkan simulasi $\mathrm{B}$, jika Indonesia ikut meratifikasi liberalisasi WTO setelah melaksanakan perjanjian liberalisasi dengan ASEAN, Korea dan Jepang, hasil simulasi menunjukkan bahwa surplus perdagangan produk sensitif dan produk jasa semakin turun dibandingkan kondisi dalam simulasi A. Namun, kondisi ini dikompensasi dengan peningkatan kinerja ekspor produk pertanian lain, terutama dari perkebunan dan produk manufaktur.

Tabel 4. Dampak Liberalisasi terhadap Surplus Perdagangan

\begin{tabular}{lccrrr}
\hline \multicolumn{1}{c}{ Deskripsi } & Indonesia & ASEAN Lain & Korea & Jepang & \multicolumn{1}{c}{ MFN } \\
\hline \multicolumn{4}{c}{ A. Liberalisasi Saat Ini } \\
Produk Sensitif Indonesia & -12.5 & 7.0 & -0.7 & -1.7 & 7.9 \\
Produk Pertanian Lain & 240.8 & -30.0 & -36.3 & -70.3 & -30.6 \\
Produk Manufaktur & 421.4 & -159.9 & 5.1 & 89.5 & -326.1 \\
Produk Jasa & -721.8 & -5.2 & -58.3 & -21.5 & $1,137.1$ \\
\hline & B. Simulasi Liberalisasi WTO & & & \\
\hline Produk Sensitif Indonesia & -25.9 & 14.1 & -0.6 & -2.1 & 14.7 \\
Produk Pertanian Lain & 734.3 & 10.2 & -23.4 & -24.6 & -742.4 \\
Produk Manufaktur & 971.0 & -220.8 & -13.9 & 116.4 & -912.4 \\
Produk Jasa & $-1,401.7$ & 66.6 & -34.7 & 8.6 & $1,869.2$ \\
\hline
\end{tabular}

Sumber : GTAP v.6, diolah

Jika dibandingkan dengan negara mitra, ternyata kinerja perdagangan Indonesia untuk produk sensitif (beras, gula, miras) jauh lebih rendah dibandingkan ASEAN lain, dimana eksportir utama untuk produk beras dan gula dimita tersebut adalah Vietnam dan Thailand. Kondisi yang sama terjadi untuk simulasi A dan simulasi B, dimana penurunan surplus perdagangan menunjukkan Indonesia lebih menjadi negara importir dibandingkan negara eksportir.
Hasil simulasi juga menunjukkan bahwa kesejahteraan Indonesia meningkat lebih tinggi dibandingkan negara lain sebagai akibat pelaksanaan liberalisasi, baik untuk simulasi A maupun B. Hal ini lebih disebabkan jumlah penduduk Indonesia jauh lebih besar dibandingkan negara lain. Namun, berdasarkan simulasi tersebut, terlihat bahwa kesejahteraan semakin meningkat setelah Indonesia ikut melaksanakan liberalisasi WTO. 
Tabel 5. Dampak Liberalisasi terhadap Kesejahteraan

\begin{tabular}{lrr}
\hline Deskripsi & A. Liberalisasi Saat Ini & B. Simulasi Liberalisasi WTO \\
\hline Indonesia & 930.9 & $2,020.2$ \\
ASEAN & & \\
Lain & -219.1 & -331.3 \\
Korea & 29.8 & 8.1 \\
Jepang & 9.0 & -53.4 \\
MFN & -923.2 & $-1,249.5$ \\
\hline Sumber : GTAP v.6, diolah & &
\end{tabular}

\subsection{Dampak Liberalisasi Terhadap Produksi Nasional}

Hasil simulasi menunjukkan bahwa produksi nasional hampir tidak mengalami perubahan sebagai akibat pelaksanaan liberalisasi dalam simulasi A maupun B. Namun terlihat bahwa pelaksanaan liberalisasi Indonesia dengan ASEAN, Korea dan Jepang sudah memberikan dampak baik bagi peningkatan produksi nasional. Namun, jika setelah itu Indonesia ikut meratifikasi liberalisasi WTO, dampaknya terhadap peningkatan produksi nasional meningkat semakin pesat.

Tabel 6. Dampak Liberalisasi terhadap Produksi Nasional

\begin{tabular}{lrrrrr}
\hline \multicolumn{1}{c}{ Deskripsi } & Indonesia & ASEAN Lain & Korea & Jepang & MFN \\
\hline A. Liberalisasi Saat Ini & & & & & \\
\hline Produk Sensitif Indonesia & 0.2 & 0.0 & 0.0 & 0.0 & 0.0 \\
Produk Pertanian Lain & 0.4 & 0.0 & -0.1 & 0.0 & 0.0 \\
Produk Manufaktur & -0.1 & 0.0 & 0.0 & 0.0 & 0.0 \\
Produk Jasa & -0.1 & 0.0 & 0.0 & 0.0 & 0.0 \\
\hline B. Simulasi Liberalisasi WTO & & & & & \\
\hline Produk Sensitif Indonesia & 0.8 & 0.1 & 0.0 & 0.0 & 0.0 \\
Produk Pertanian Lain & 1.5 & 0.1 & 0.0 & 0.0 & 0.0 \\
Produk Manufaktur & -0.4 & 0.0 & 0.0 & 0.0 & 0.0 \\
Produk Jasa & -0.2 & 0.0 & 0.0 & 0.0 & 0.0 \\
\hline Sua
\end{tabular}

Sumber : GTAP v.6, diolah

Hasil simulasi juga menunjukkan bahwa liberalisasi ini nyaris tidak mempengaruhi kinerja produksi negara mitra. Hal ini menunjukkan bahwa liberalisasi tersebut lebih banyak mendorong terciptanya trade diversion (pengalihan ekspor-impor) dibandingkan trade creation (peningkatan volume ekspor-impor).

\subsection{Dampak Liberalisasi terhadap Perubahan Impor Indonesia}

Hasil simulasi A menunjukkan bahwa peningkatan impor produk sensitif Indonesia terutama beras dan gula lebih banyak berasal dari sesama negara ASEAN, antara lain Thailand dan Vietnam dibandingkan negara lain. Hal yang sama juga terjadi untuk impor produk pertanian lainnya, kecuali manufaktur dan jasa. Untuk kedua produk tersebut, negara yang dapat menembus pasar Indonesia lebih baik dari yang alin adalah Jepang. 
Tabel 7. Dampak Liberalisasi terhadap Impor Indonesia

\begin{tabular}{|c|c|c|c|c|c|}
\hline & ASEAN Lain & Korea & Jepang & MFN & Total \\
\hline \multicolumn{6}{|c|}{ A. Liberalisasi Saat Ini } \\
\hline $\begin{array}{ll}\text { Produk } & \text { Sensitif } \\
\text { Indonesia } & \end{array}$ & 173.4 & 0.6 & 4.8 & 50.8 & 229.6 \\
\hline Produk Pertanian Lain & $1,777.8$ & 212.4 & $1,168.2$ & $4,859.8$ & $8,018.2$ \\
\hline Produk Manufaktur & $10,908.1$ & $4,242.9$ & $11,913.4$ & $32,502.9$ & $59,567.3$ \\
\hline Produk Jasa & 151.1 & 73.2 & 271.8 & $3,324.0$ & $3,820.1$ \\
\hline Total & $13,010.5$ & $4,529.2$ & $13,358.1$ & $40,737.5$ & $71,635.3$ \\
\hline \multicolumn{6}{|c|}{ B. Simulasi Liberalisasi WTO } \\
\hline $\begin{array}{l}\text { Produk Sensitif } \\
\text { Indonesia }\end{array}$ & 166.2 & 0.6 & 4.6 & 48.6 & 220.0 \\
\hline Produk Pertanian Lain & $1,606.6$ & 191.8 & $1,045.2$ & $6,017.3$ & $8,860.9$ \\
\hline Produk Manufaktur & $9,867.9$ & $3,846.4$ & $10,802.6$ & $37,294.5$ & $61,811.4$ \\
\hline Produk Jasa & 142.1 & 68.8 & 255.7 & $3,126.3$ & $3,592.9$ \\
\hline Total & $11,782.7$ & $4,107.7$ & $12,108.1$ & $46,486.7$ & $74,485.2$ \\
\hline
\end{tabular}

Sumber : GTAP v.6, diolah

Hasil simulasi B juga menunjukkan bahwa ratifikasi perjanjian WTO relatif tidak merubah pola impor Indonesia. Indonesia tetap mengimpor produk pertanian dalam jumlah besar dari negara ASEAN, dan sebagaian dari negara yang dikenakan tarif internasional (MFN) seperti halnya Amerika, Australia dan Uni Eropa. Namun terlihat bahwa hasil simulasi menunjukkan bahwa impor produk sensitif dan produk pertanian Indonesia lebih kecil dalam simulasi B dibandingkan dalam simulasi A.

Hasil simulasi yang menunjukkan liberalisasi multilateral menyebabkan impor yang lebih kecil dibandingkan liberalisasi regional ini sesuai dengan temuan dari Burfisher (2001). Dalam kajiannya Burfisher menyatakan bahwa liberalisasi multilateral akan mendorong alokasi sumber daya dan menciptakan perdagangan yang lebih adil dan sesuai dengan daya saing setiap negara.

\section{Kesimpulan}

Kesimpulan yang dapat diambil dari kajian ini adalah pertama, impor beras dan gula cenderung meningkat semenjak tahun 2007 sampai saat ini, namun hal ini lebih disebabkan peningkatan konsumsi yang belum dapat diimbangi oleh peningkatan produksi. Kedua, Indonesia telah melakukan liberalisasi dengan negara mitra dagang utama yaitu ASEAN, Korea dan Jepang, sehingga liberalisasi WTO tarif tidak akan memberikan dampak sebesar liberalisasi dengan mitra utama tersebut. Ketiga, kajian menemukan bahwa impor beras dan gula tidak signifikan dipengaruhi pelaksanaan liberalisasi, hal ini disebabkan peningkatan impor karena penurunan produksi bukan karena keikutsertaan Indonesia dalam perjanjian perdagangan bebas.

Oleh karena itu, untuk meningkatkan ketahana pangan komoditas beras dan gula, direkomendasikan untuk meningkatkan produktifitas sektor pertanian terutama tanaman pangan jika 
tetap ingin bersaing dalam era liberalisasi. Untuk meningkatkan produktifitas tersebut, terdapat beberapa masalah domestik yang harus segera diatasi antara lain: persaingan lahan antara produk pangan dengan perkebunan dan pemanfaatan lain, infrastruktur penunjang pertanian yaitu irigasi dan gudang, riset peningkatan produktifitas pertanian, serta penyediaan saprodi yang tidak merugikan petani.

\section{Daftar Pustaka}

Apriyantono, A. 2006. "Liberalisasi Perdagangan dan Pembangunan Pertanian". Bahan Kuliah Umum Menteri Pertanian Pada Program Magister Ilmu Hubungan Internasional Fakultas Ilmu Sosial Dan Ilmu Politik Universitas Indonesia, Jakarta.

Anderson, J. A. 1996. "Effective Protection Redux". NBER Working Paper Series No. 5854.

Aswicahyono, H. 2004. "Competitiveness and Efficiency of the Forest Product Industry in Indonesia". Policy Paper Series on The Impact of the Economic Crisis on the Forestry Sector in Indonesia, a CSIS-John D and Catherine T. Mac Arthur Foundation Project, February.
Burfisher, M. E.. 2001. "The Road Ahead: Agricultural Policy Reform in the WTO--Summary Report". Agricultural Economic Report No. (aer797) 32 pp, January.

Departemen Perdagangan, 2009. "Menuju Daya Saing Bangsa dan Kemakmuran Rakyat". Pembangunan Perdagangan 20052009. Jakarta.

Hertel dan Tsigas. 1997. "Structure of GTAP, Global Trade Analysis, Modeling and Applications". Cambridge University Press, New York.

McCallum, J. 1995. "National Borders Matter: Canada-US Regional Trade Patters". American Economic Review. June, 85(3), pp.615-623.

Susastro, H. 2004. "Kebijakan Persaingan, Daya Saing, Liberalisasi, Globalisasi, Regionalisasi dan Semua Itu". Economic Working Papers Series. CSIS, Jakarta.

Tambunan, T. 2008. "Ketahanan Pangan di Indonesia Inti Permasalahan dan Alternatif Solusinya". Makalah dipersiapkan untuk Kongres ISEI, Mataram. 